Meta

Journal des traducteurs

Translators' Journal

\title{
Consecutive Interpreting in Advanced Language Work
}

\section{J. K. Hill}

Volume 24, numéro 4, décembre 1979

URI : https://id.erudit.org/iderudit/003071ar

DOI : https://doi.org/10.7202/003071ar

Aller au sommaire du numéro

Éditeur(s)

Les Presses de l'Université de Montréal

ISSN

0026-0452 (imprimé)

1492-1421 (numérique)

Découvrir la revue

Citer cet article

Hill, J. K. (1979). Consecutive Interpreting in Advanced Language Work. Meta, 24(4), 442-450. https://doi.org/10.7202/003071ar d'utilisation que vous pouvez consulter en ligne.

https://apropos.erudit.org/fr/usagers/politique-dutilisation/ 


\section{Consecutive Interpreting in Advanced Language Work*}

J. K. HILL

Advanced learners of a foreign language tend to reach a point in their studies where they feel that they are no longer improving their skills, or indeed in extreme cases that they are losing what fluency they had. Sometimes this may actually be happening, where the emphasis of a course is moving from language to content, institutions or more usually literature. More often the feeling is a manifestation of the economists' theory of diminishing marginal efficiency : the value of one more unit of language practice is felt to be so slight in relation to the total knowledge of the language acquired over the years that the student either undertakes the practice and is then disappointed, or worse, decides that it is not worth while making the effort.

In the context of the English educational system French is particularly prone to this danger because it is almost universally studied in school as the first or only foreign language, so that students entering university have usually 6 or 7 years of French studies behind them. Those who begin a second language in the sixth form or at university inevitably feel that they are achieving more in this new area, and sometimes become despondent about their apparent lack of progress in French. Motivation is not helped by the fact that there is no clearly demarcated transition between the sixth form and the traditional university course. Since it is the expectations of university departments which largely determine the form of the GCE Advanced Level examination which in turn conditions the sixth form syllabus and methodology, the student may well feel that university work based on translation and literature is just more of the same.

The advent of a different kind of degree course in which a foreign language is taught in conjunction with a discipline in the social sciences or the natural sciences rather than with literature has led to a reappraisal of the kind of language skills likely to be of use to social or natural scientists. The Language Centre at the University of Kent is responsible for the language component of a variety of three and four-year degree courses in Politics with a Language, Law with a Language and European Studies. In the first year of the French course the main emphasis is on effective reading in the foreign language in order to give students the confidence to tackle quite long and specialised articles in the journals

* Paper read at the 5th International Congress of Applied Linguistics, August 1978, Montreal. 
of their discipline, on aural comprehension and oral expression to facilitate field work and participation in international conferences, and on essay writing to maintain and develop accurate use of the written language. The whole basis of the course is therefore quite different to that of the final years at school and considerably more practical. Students make progress and motivation is generally good.

In the second year the same aims are maintained, and it is here that consecutive interpreting has been introduced to exploit the students' growing language skill and to provide fresh motivation in the form of a new challenge guaranteed to keep even the most talented among them at full stretch. Be it said at this point that there is absolutely no intention to train professional interpreters, we are dealing with Social Scientists who will also be good linguists. Nor is it intended that interpreting should be the sole or even the main method of work, but rather a lively and demanding supplementary way of practising language skills. It takes its place in an integrated course as one of the forms of language output.

MODEL OF AN ALL-SKILLS LANGUAGE COURSE

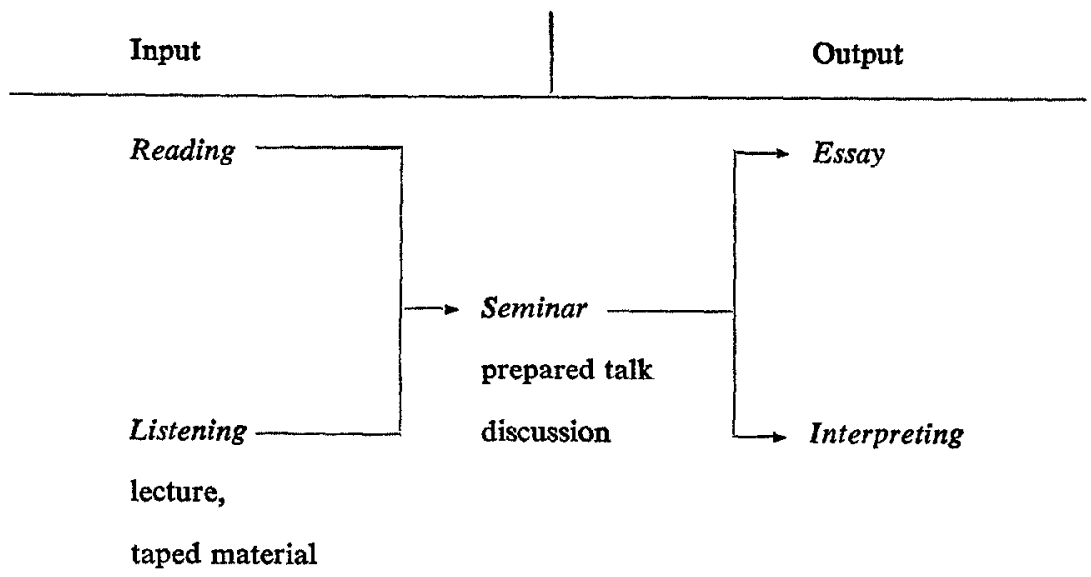

Translation and résumé exercises are used where appropriate either as input or output.

One very simple and flexible method of running an interpreting class consists of reading aloud a printed text to a group and requiring them in turn to render it into another language. A number of advantages are immediately apparent : the text is chosen for its interest and for the quality of its content and language which are guaranteed since the author is presumably a specialist in his field; the teacher reads it at what he judges to be the optimum speed for his group, and divides it up into sections of appropriate length. As he does not have to create the material, he is free to listen to their attempts; having prepared his own fair copy beforehand, he is ready to resolve their difficulties, and, should he so desire, he can hand out copies of the original text for further close study and detailed comparison of alternative versions. 
From the student's point of view the shortcomings of this approach are equally clear : he hears only the voice of the teacher, and he is limited to the delivery of reading aloud and to the style of the printed word. He is in fact doing oral translation without having the text in front of him, which is a valid exercise in its own right but which lacks the variety and the spontaneity of genuine oral discourse.

Ideally then the interpreting class needs spontaneous speech as its raw material. So the teacher lectures on the problems of society or holds forth to the best of his ability about current affairs. Better still, he invites a colleague to join him, thus creating a dialogue with two voices and two contrasting visions of the world. This is more lively material for the interpreter, with changes of pace and density, occasional repetitions or false starts, a few colloquialisms and a chance of a bit of humour.

However, this dialogue, lively as it is, will almost inevitably be more superficial than the printed text from the point of view of both content and specialized language. Furthermore, now that the teacher is involved in creating the source material, listening to the other side of the argument and preparing his next point, he no longer has any time to devote to listening to what the students are doing. So a third member of staff is needed for the original job of running the interpreting class, controlling the flow of the source and correcting the efforts of the students. Finally, with this approach using spontaneous ephemeral dialogue, the stage of close study depends on the completeness of the notes taken by the various participants.

The accusation of superficiality is extremely serious. One of the great strengths of the translation method of language teaching lies in the fact that it is always a pleasure to work with original texts of the highest quality. Without attempting to rival Proust or Lawrence, it is possible to produde excellent dialogues for interpreting by investing time and effort in preparation. The speakers should agree a starting point, and if possible, foresee some of the main lines that might be explored. More particularly they need to fill the gaps in their knowledge of the subject to be discussed and to familiarize themselves with the appropriate register of language and the specialized terminology. In fact, in order to prepare a meaningful dialogue for interpreting the speakers have to prepare themselves rather in the same way as the professional interpreter gets ready for an assignment in an area with which he is not entirely familiar. Having said that, it would be a mistake to take the preparation too far. More would be lost than gained if the dialogule were to be scripted beforehand. The impression of freshness and spontaneity must remain.

Once the need for serious preparation is recognized, the advantages of finding at least one specialist quickly becomes apparent. Someone who spends his professional life dealing with a particular kind of problem and speaking the language of that specialism has been prepared in the best possible way to take part in dialogues. Thus an information scientist is interviewed about the uses and abuses of the computer, a professor of politics about the power of the French President and a social worker about drug addiction. 
After working so hard at providing authentic dialogues by various means, it would be wasteful not to record them for future use. Having the source material for the interpreting class available on tape solves several other problems. The teacher, relieved of the responsibility of creating dialogue during the actual class, is once again free to concentrate on his group, and linguistic preparation and follow-up greatly facilitated.

Monolingual dialogues in English or French can often be found ready made on the radio, complete with specialists and, even more valuable, field work type interviews with delinquents in prison and trade unionists on the shop floor. However, there will always be a place for the studio dialogue specially produced to coincide with the student's course content and precise stage of language development. More particularly, for our own purposes, we create and use bilingual dialogues between a native speaker of English and a native speaker of French (at least one of whom should be an expert in his field) each functioning in his own language. In practice the production of spontaneous dialogue is greatly facilitated if the two speakers really do understand the other language. As far as the student is concerned of course they do not. He is therefore in the situation of the liaison interpreter working alternately from English to French and from French to English. The constant switching requires concentration, and it is occasionally necessary to point out that there is no particular virtue in interpreting perfectly good Frenchman's French into rather less good English student's French. Sometimes the actual difficulty of finding equivalents turns out to be reduced by the fact that both languages are in use since the correct form may turn up in each language quite naturally in the course of the exchange. Certainly the whole operation takes on a more realistic air : consecutive interpreting of a monolingual conversation may seem to be strictly a language exercise or a job for the professional, whereas the need for person to person liaison interpreting is a common experience of every linguist. Here we have two well-informed people with a subject of great mutual interest and an urgent desire to communicate; it would be churlish of the linguist not to oblige them.

With the particular needs of our own students in mind we have so far produced bilingual interviews in the following subject areas :

overseas aid

education - attitudes of young people

- elitism of the Grandes Ecoles

immigration - problems of immigrants

- training

language

literary criticism

politics - elections

- the French President

- local government

foster homes for young people in trouble

computers and computing

urbanism - house purchase

- slum clearance

- housing policy 


\section{Methodology}

The dialogues, bilingual or monolingual, can well be used in a seminar type class with a tape recorder. The members of the group listen to each section, take their own notes and interpret in turn. Alternative renderings are suggested and discussed. As in any classroom situation, the individual is not constantly in action, but, as he hears all that is going on, he benefits from the work of the group and the discussion arising from other people's errors.

In the language laboratory, on the other hand, each student in the privacy of his booth has to tackle everything himself without the support of the group and without the immediate guidance of the teacher. He is required to make a sustained personal effort, to muster all his language experience and every last ounce of ingenuity to rise to the occasion. There is no doubt that this situation creates a pressure on the student, and it is the responsibility of the teacher to make sure that it is a healthy pressure leading him to discover solutions which are within his capabilities. It is obviously counter-productive to create a sense of failure and frustration by trying to force him to tackle texts which are too difficult for him. For instance, it is perfectly fair to expect advanced students to find an acceptable version of expressions like :

$I$ felt bad about it - je me sentais mal j'étais mal à l'aise j'avais des remords je n'avais pas la conscience tranquille cela me gênait

but they cannot possibly produce technicalities unless they have previously come across them : traitement direct, traitement différé - on-line and batch processing. Assuming that interpreting is being used as an output stage to practise language already fed in by other types of activity, there should be no problems of this nature. However, it is usually worthwhile spending a few minutes at the beginning of each session to verify key words and discuss major stumbling blocks. A little assistance at the outset often brings a disproportionate improvement in confidence and hence in the quality of the work done.

The laboratory can be used in a variety of ways. For some purposes it may be unnecessary to record either the source or the student's version, so the booth is used simply as a reception point and a private place to work. More usually it will be useful if the student has the possibility of listening again to the source and to himself, and eventually of making a second improved version. The most usual way of providing for this is to pre-explode the source tape, dividing it into sections of appropriate length and leaving a gap after each section for the interpretation. The problem here is the length of the gap. It is relatively easy to calculate the right length for transformation drills or answers to straightforward questions, but students vary considerably in the time they take to interpret sections of dialogue of from 20 - 30 seconds duration. A good linguist will give the main points quickly and concisely, often in less time than the original, while lesser talents will fumble and stumble for twice as long. In any case pre-exploded 
gaps, however carefully calculated, are bound to be the wrong length for at least half of any given group, and this is a source of distraction and irritation.

To overcome this difficulty a more flexible method is necessary. Students are installed in their booths with a blank tape. The first section of dialogue is recorded from the console, and the students then record their interpretation, taking as long as they need within reason and each stopping his own machine. When everyone has finished, the second section of dialogue is recorded from the console and so on. In this way each student has a tailor-made exploded version geared to his own rhythm of work which he can re-use during the same laboratory period or at some later time in private study.

Finally, when it is intended to assess the student's work, the source dialogue is broadcast to the booths but not recorded. The student records his interpretation, stopping the machine each time he finishes a section. The final product is therefore a continuous recording of the student's version, which can be assessed against the transcript of the original.

However the laboratory is used, it is impossible for the teacher to do more than selective monitoring, and it is therefore essential to leave time at the end of each session to put right errors actually heard, to discuss alternative versions and to answer questions. This part of the class is greatly facilitated if a transcript of the original dialogue is made available to students. One other method of monitoring and correction can be used with good effect if a conference room or interpreting laboratory is available. The students are paired off, with one of each pair established in a recording booth while his opposite number sits in a delegate's seat and tunes in to his booth. Thus each « interpreter » is monitored all the time, and, as the «delegates » take the responsibility seriously, the follow-up sessions can be quite heated. The pairs change places at the half-way mark.

So far consideration has been given mainly to the point of view of the teacher. Having analysed his students' needs, he has decided to give them practice in interpreting. He has produced appropriate dialogues of high quality, decided on his methodology and prepared his fair copies. The time has now come for the student to take up the challenge, to make use of the language skills which he has perfected over the years.

When the original is in French his main problems are likely to arise in comprehension. As in real life, he will not expect to encounter in the interpreting booth only educated speakers using a standard academic register in studio conditions. Difficulties arising from regional and social differences, accent intonation and speed of delivery, are likely to be compounded by less than perfect listening conditions, in a cafe or a factory or on the telephone. The only possible solution here is for the long term : listening practice until the ear is as sharp as the native speaker's.

If on the other hand the problem is one of vocabulary, he should be alert to seize on what help is available in the context

"Je ne vis que pour ma moto, je suis dingue de la moto. "

... I'm mad on motor bikes. 
«Pour moi la moto c'est un moyen d'expression, c'est un défoulement. »

... it's a way of letting off steam.

«Il se trouve en tête du Top Inter, et il a fait cinq tubes. »

... five hits.

Usually when he has found a good equivalent in English no further explanation is needed :

embaucher un ouvrier et

licencier un ouvrier

to sign on and

to lay off a worker

However, the interpreter will sometimes encounter concepts which have no strict equivalent in English and which need an explanation rather than a translation :

He must know what an «agrégé » is and a «marchand de sommeil » and what happens when a candidate is «en ballottage» or «un énarque est classé dans la botte $»$. He must also move freely in the world of abbreviations, where people live in an HLM, study at the local CES, work as OS, prepare for their CAP, go in fear of the CRS, hope one day to become PDG of the firm, but remain smigards and cégétistes. So the interpreting class is the proving ground not only for language but for knowledge of life and institutions.

Whatever the source language, the interpreter is expected to understand everything. However, he is unlikely to be able to note ${ }^{1}$ down or otherwise retain every detail. Ideally he absorbs all that is actually said in the first language and produces in the second language a running summary of the main lines with as much of the additional detail as he can manage. A good deal depends on the style of the speaker. Sometimes the original is so concise and so dense that it is almost impossible to shorten it :

\& Depuis près de 10 ans, l'opposition a critiqué la politique du logement du gouvernement en place : en particulier le nombre d'habitations construites. Au $6^{\mathrm{e}}$ Plan il en est prévu entre 400000 et 500000 par an mais cela ne correspond pas aux besoins qui sont estimés à plus de 700000 par an.

L'augmentation des prix à la construction est phénoménale. Le fait que l'aide tend à profiter beaucoup plus à ceux qui n'en ont pas besoin qu'à ceux qui en ont besoin est aussi une caractéristique du système français.»

By comparison the following example is verbose and repetititive :

«On a affaire à des garçons qui ont beaucoup de mal à sortir d'eux-mêtnes, qui sont fermés dans leur personnage et qui ont du mal à pouvoir reconnaître à côté d'eux l'existence de quelqu'un d'autre, des garçons incapables d'appréhender une situation moralement en dehors de leurs propres critères à eux, qui sont incapables de se mettre à la place de l'autre. »

Here the interpreter uses his discretion and gives the main point much more economically :

1. Note taking is an important subject in its own right; but rather outside the strict lines of the present paper. See : Rozan, «La prise de notes en interprétation consécutive », Librairie de l'Université Georg, Geneva, 1970. 
«We are dealing with boys who are so deeply immersed in themselves that they have absolutely no consideration for anyone else. 》

When the original is in English, the main problem for the English student is to produce a smooth flow of idiomatic French. Here, of course, as with any skill, practice is vital. One particular aim should be to increase his stock of automatic associations of words, so that, even under pressure of time, a verb summons up the right noun to go with it :

$\begin{array}{ll}\text { se consacrer } & - \text { se consacrer à une tâche } \\ \text { entraîner } & \text { entraîner des conséquences } \\ \text { éprouver } & - \text { éprouver un sentiment } \\ \text { préconiser } & - \text { préconiser une solution }\end{array}$

and a noun the right verb :

bilan

- dresser un bilan

candidature

- poser sa candidature

conclusion

- tirer une conclusion

pression - exercer une pression

Similarly a certain group of words in one language should trigger off an equivalent expression in the other language :
to create a problem
- poser un problème
to run into a problem
- se heurter à un problème
the facts of the problem - les données du problème
to solve a problem _ résoudre un problème
the way they solved the problem - la solution apportée au problème

His growing experience of the two languages helps him to avoid anglicisms :

to realise the full horror of the situation requires «se rendre compte » not «réaliser»

to control a large firm is « diriger» rather than «contrôler »

When no obvious equivalent springs to mind, he will seek ways round the obstacle, perhaps by looking for a synonym in the source language : "lawbreaker » for instance has no cognate in French, but « criminal » or « delinquent » provides an easy solution. Sometimes it is necessary to find a different way of expressing an idea :

to keep wages down _ - limiter la hausse des salaires

Sometimes a negative turn of phrase is the right answer :

I'm a layman in this field _ _ je ne suis pas spécialiste en la matière

Eventually the linguist with a flair for this kind of work will get enormous satisfaction from producing expressions which he knows to be exactly right in the context, and certainly better than the more literal version which would have satisfied him a few months earlier :

overt hostility

- hostilité déclarée

lower the prestige of

- dévaloriser 
So, although the course has no pretentions to turn out professional interpreters, the skills that they require are worth pursuing for their own sake : an exoellent knowledge of the two languages and the ability to transpose ideas fluently from one to the other, broad general knowledge and a profound insight into the culture of the countries; the analytic skill to see the main points of an argument; and a host of other talents, short-term memory, presence of mind, ingenuity and the nerve to escape from difficult linguistic situations quickly and unobtrusively. There is no reason why the more modest linguist should not aim high and aspire to master techniques which are both challenging and relevant. 